\title{
Apoptosis induced by staurosporine in ECV304 cells requires cell shrinkage and upregulation of $\mathrm{Cl}^{-}$ conductance
}

\author{
AM Porcelli ${ }^{1}$, A Ghelli ${ }^{1}$, C Zanna ${ }^{1}$, P Valente ${ }^{2}$, S Ferroni ${ }^{2}$ and \\ M Rugolo*,1 \\ ${ }^{1}$ Dipartimento di Biologia Evoluzionistica Sperimentale, Via Irnerio 42, \\ Università di Bologna, Bologna 40126, Italy \\ 2 Dipartimento di Fisiologia Umana Generale, Via S. Donato 19/2, Università di \\ Bologna, Bologna 40126, Italy \\ * Correspondence: M Rugolo, Dipartimento di Biologia Evoluzionistica \\ Sperimentale, Università di Bologna, Via Irnerio 42, Bologna 40126, Italy. \\ Tel.: + 39-051-2091306; Fax: + 39-051-242576; \\ E-mail: michela.rugolo@unibo.it
}

Received 16.9.03; revised 03.12.03; accepted 23.12.03; published online 13.2.04 Edited by Dr J Lockshin

\begin{abstract}
We show that dysregulation of the $\mathrm{Cl}^{-}$homeostasis mediates the staurosporine-induced apoptotic cell death in human ECV304 cells. A pronounced apoptotic volume decrease (AVD), and an increase in plasma membrane $\mathrm{Cl}^{-}$conductance were early $(<1 \mathrm{~h})$ events following staurosporine challenge. Both processes were involved in apoptotic death, as demonstrated by the observation that the $\mathrm{Cl}^{-}$channel blocker phloretin inhibited both the staurosporine-evoked $\mathrm{Cl}^{-}$current and AVD, and preserved cell viability. Prolonged incubation $(>2 \mathrm{~h})$ with staurosporine caused a decrease in intracellular $\mathrm{pH}$, which, however, was not required for the progression of the apoptotic process, because inhibitors of proton extrusion pathways, which lowered cytoplasmic $\mathrm{pH}$, failed to inhibit both caspase-3 activation and DNA laddering. Moreover, clamping the cytosolic $\mathrm{pH}$ to an alkaline value did not prevent the apoptotic cell death. Collectively, these data demonstrate that staurosporine-mediated apoptosis of ECV304 cells is caused by the upregulation of $\mathrm{Cl}^{-}$channel activity and subsequent AVD, but is independent of intracellular acidification.

Cell Death and Differentiation (2004) 11, 655-662.

doi:10.1038/sj.cdd. 4401396

Published onine 13 February 2004
\end{abstract}

Keywords: apoptotic volume decrease; chloride channel; cytochrome $c$; caspase-3; intracellular pH; ECV304 cells

Abbreviations: BCECF, 2',7'-bis(2-carboxyethyl)-5(6)carboxy fluorescein tetraacetoxy methylester; DIDS, 4,4'-diisothio cyanatostilbene-2,2'-disulfonic acid; $\mathrm{H}_{2}$ DIDS, 4,4'-diisothiocyanatodihydro stilbene-2,2'-disulfonic acid; high $\mathrm{K}^{+}$medium, medium with elevated $\mathrm{K}^{+}$concentration; MTT, 3-(4,5-dimethyl thiazol-2yl)-2,5-diphenyl tetrazolium bromide; NPPB, 5-nitro-2-(3-phenylpropyl amino) benzoic acid; $\mathrm{pH}_{\mathrm{i}}$, intracellular $\mathrm{pH}$

\section{Introduction}

The homeostatic balance of ions across the plasma membrane not only appears to be required for the control of the cell size but also seems to be involved in the maintenance of cell viability. This evidence was recently strengthened by a series of studies showing that a dramatic decrease in intracellular monovalent ions occurs during apoptosis. ${ }^{1,2}$ Accumulating evidence suggests that the cellular outflow of $\mathrm{K}^{+}$and $\mathrm{Cl}^{-}$ ions, followed by osmotically obliged water, leads to normotonic cell shrinkage, the characteristic loss of cell volume called apoptotic volume decrease (AVD) (see, for recent reviews, Lang et al. ${ }^{3}$, Okada et $a l^{4}$ and Bortner and Cidlowski ${ }^{5}$ ). Numerous electrophysiological studies have revealed that in different cellular systems, apoptotic stimuli caused an enhancement of $\mathrm{K}^{+}$efflux through the upregulation of voltage-gated outward $\mathrm{K}^{+}$currents, ${ }^{6-8} \mathrm{Ca}^{2+}$-activated $\mathrm{K}^{+}$channels ${ }^{9,10}$ or two-p-domain $\mathrm{K}^{+}$channels. ${ }^{11,12}$ In other cell types, the augment in channel-mediated $\mathrm{K}^{+}$efflux was paralleled by an increase in $\mathrm{Cl}^{-}$conductance. ${ }^{13}$ Finally, it was reported that several apoptotic stimuli induced the selective upregulation of $\mathrm{Cl}^{-}$channel activity. ${ }^{14,15}$ However, whether activation of $\mathrm{Cl}^{-}$channels has a causative role in AVD and apoptosis still remains to be firmly established. In this context, by examining various cell lines exposed to different apoptotic stimuli, it was recently shown that the separate pharmacological blockade of volume-regulatory $\mathrm{K}^{+}$and $\mathrm{Cl}^{-}$channels prevented AVD and subsequent apoptotic cell death. ${ }^{16}$

An alteration of the ion transport mechanisms responsible for the regulation of intracellular $\mathrm{pH}\left(\mathrm{pH}_{\mathrm{i}}\right)$ has also been suggested to be involved in the modulation of the death process, although contradictory results have been reported. In fact, it was shown that during apoptosis induced by the removal of IL-7 from D1-T cell line, $\mathrm{pH}_{\mathrm{i}}$ increased to a value of 7.8 , leading to a conformational change of the proapoptotic $\mathrm{Bcl}-2$ family protein Bax, which was followed by its translocation into the mitochondrial membrane. ${ }^{17}$ Bax translocation has also been described in HeLa cells treated with staurosporine or tumor necrosis factor- $\alpha(\mathrm{TNF}-\alpha)$, in spite of the fact that the two molecules produced opposite effect on $\mathrm{pH}_{\mathrm{i}}{ }^{18}$ Other studies have indicated that apoptosis is associated with intracellular acidification, which may be due to the inhibition of $\mathrm{H}^{+}$efflux transport mechanisms, such as the $\mathrm{Na}^{+} / \mathrm{H}^{+}$ exchanger ${ }^{19,20}$ and the vacuolar ATPase ${ }^{21}$ or both. ${ }^{22}$ According to some reports, acidification might also occur, at least in part, as a consequence of the reversal operation of the mitochondrial ATP synthase. ${ }^{23}$ The question as to whether intracellular acidification is necessary for inducing apoptosis or occurs as a consequence of caspase activation remains an issue of debate. A detailed analysis revealed that in somatostatin-induced apoptosis, caspase-8 activation was required for cytosolic acidification, which, in turn, triggered 
cytochrome $c$ release as well as the activation of the effector caspase-3, -7 and $-9 .^{24}$

We previously reported that the incubation of ECV304 endothelial cells with the bacterial alkaloid staurosporine caused a great reduction in cell viability, which was accompanied by the occurrence of some typical hallmarks of apoptotic cell death. ${ }^{25}$ In the present study, we have attempted to dissect the temporal sequence of the biochemical events characterizing the apoptotic process, such as the release of cytochrome $c$, activation of caspase-3, and nuclear DNA fragmentation. Furthermore, we have addressed the issue of the possible link between the staurosporine-induced AVD, which was apparent at the very early stage of the apoptotic process, and a change in plasma membrane ionic permeability. We demonstrate that in ECV304 cells staurosporine generated a rapid increase in $\mathrm{Cl}^{-}$conductance, which was accompanied by a lowering of $\mathrm{pH}_{\mathrm{i}}$. Finally, we provide evidence that the increase in $\mathrm{Cl}^{-}$channel activity, but not the cytosolic acidification, is instrumental for AVD, and that the blockage of the staurosporine-evoked $\mathrm{Cl}^{-}$current by using a specific inhibitor of volume-sensitive $\mathrm{Cl}^{-}$channels abrogates the apoptotic cell death of ECV304 cells.

\section{Results}

The incubation of ECV304 cells with $1 \mu \mathrm{M}$ staurosporine caused a time-dependent decrease in cell viability, as determined by means of 3-(4,5-dimethyl thiazol-2-yl)-2,5diphenyl tetrazolium bromide (MTT) assay (Figure 1a). A marked decrease in the number of viable cells was apparent already after $6 \mathrm{~h}$ incubation with staurosporine $(40 \pm 9 \%$, $n=6)$ and maximal after $18-24 \mathrm{~h}(63 \pm 7 \%, n=3)$. Surprisingly, these results are different from our previous observation, which indicated that cell viability, determined by the Trypan blue exclusion method, was unaffected following the incubation with staurosporine up to $10 \mathrm{~h}^{25}$ This discrepancy can be explained with the different methods utilized to assess the percentage of cell death. In fact, it is well known that Trypan blue is excluded from cells with intact plasma membrane, and cells in the early phases of apoptosis are likely to retain their membrane integrity for several hours. ${ }^{26}$ Conversely, intracellular MTT reduction, which was previously shown to be due to the activity of both mitochondrial and nonmitochondrial dehydrogenases, ${ }^{27}$ can reveal subtle alterations in cells undergoing an impaired metabolism, which occur during the early phases of the apoptotic process.

We next evaluated the temporal sequence of three typical features of staurosporine-induced apoptotic cell death of ECV304 cells, such as the release of cytochrome $c$ from mitochondria, activation of caspase-3 and nuclear DNA fragmentation. The amount of cytochrome $c$ in the cytosolic fractions isolated from cells treated with staurosporine noticeably increased starting from $4 \mathrm{~h}$ incubation and was maximal after $6 \mathrm{~h}$ or longer time periods (Figure $1 \mathrm{~b}$ ). It is well known that in the cytosol, interaction of cytochrome $c$ with apoptotic protease-activating factor- 1 and procaspase- 9 triggers the assembly of the apoptosome complex. Such macromolecular complex is required for the activation of caspase-9, which, in turn, promotes activation of further a

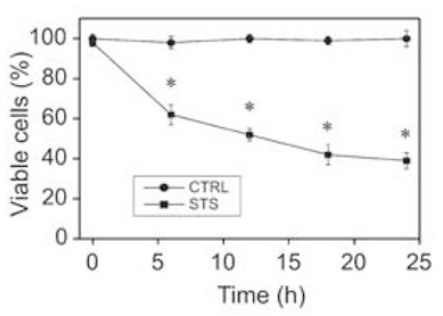

C

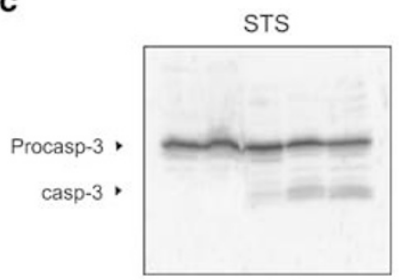

Time (h) $\quad 0 \quad 2 \quad 4 \quad 8 \quad 16$ b

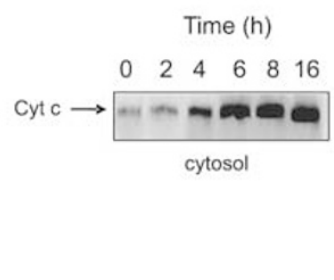

d

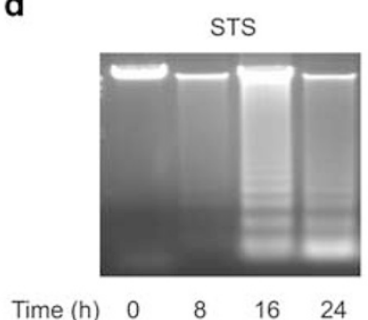

Figure 1 Time course of cell viability, cytochrome $c$ release, caspase-3 activation and DNA laddering in staurosporine-treated ECV-304 cells. Cells at confluence were incubated in serum-free M199 growth medium in the absence (CTRL) or presence of $1 \mu \mathrm{M}$ staurosporine (STS) for the time periods indicated. (a) The percentage of viable cells was measured by MTT assay. Data are expressed as means \pm S.D. of at least three independent determinations. ${ }^{*} P<0.05$, with Student's $t$-test, from CTRL at the corresponding time point. (b) Cells were homogenized and cytosolic fractions were separated by differential centrifugation, as described in Materials and methods. Proteins $(30 \mu \mathrm{g})$ were separated by tricine-SDS-PAGE and cytochrome $c$ levels were determined by Western blotting. Data are representative of three similar experiments. (c) Western blot analysis of procaspase-3 and caspase-3 levels in lysates of cells exposed to staurosporine (STS) for various time periods. Data are representative of three similar experiments. (d) Typical DNA laddering of ECV304 cells exposed to staurosporine. Nuclear DNA was separated by electrophoresis in $1 \%$ agarose gel at different time points. The results shown are representative of experiments performed at least in triplicate

caspases, among which is the effector caspase- $3 .^{28}$ The activation of caspase- 3 was evaluated by determining procaspase-3 cleavage. Figure 1c shows that a significant cleavage was apparent after $4 \mathrm{~h}$ incubation with staurosporine, and was maximal after 8-16h. Finally, nuclear DNA isolated from staurosporine-treated cells showed a weak, but significant fragmentation after $8 \mathrm{~h}$, reaching a maximum between 16 and $24 \mathrm{~h}$ of incubation (Figure 1d). Altogether, these results clearly indicate that during staurosporineinduced apoptosis of ECV304 cells, cytochrome $c$ release paralleled caspase-3 activation, and preceded the fragmentation of nuclear DNA.

A major hallmark of cells undergoing apoptosis is a normotonic reduction of cell volume termed AVD. ${ }^{3-5}$ To address this issue in relation to staurosporine-induced apoptosis of ECV304 cells, we analyzed the real-time dynamic changes of cell morphology in single cell transfected with green fluorescent protein (GFP). ECV304 cells incubated in normal growth medium exhibited a diffuse fluorescence, which depicted the typical irregular polygonal shape (Figure 2a). Cells incubated in a staurosporine-containing growth medium underwent a rapid change in cell morphology characterized by cytoplasm retraction and pronounced cell shrinkage (Figure 2b-f). The change in cell morphology was 
already apparent after 15 min (Figure $2 b$ ), progressed rapidly (Figure 2c-e) and was maximal after 120 min (Figure 2f).

As there is accumulating evidence that augmented channel-mediated transmembrane $\mathrm{K}^{+}$and $\mathrm{Cl}^{-}$fluxes play a crucial role in AVD, ${ }^{16}$ we next sought to determine whether at least part of the staurosporine action could be due to its ability to upregulate channel activity compatible with AVD. Cells were voltage clamped at a holding potential $\left(V_{h}\right)$ of $-60 \mathrm{mV}$ and stimulated with voltage ramps from -120 to $+60 \mathrm{mV}$ (Figure $3 \mathrm{a}$ inset). Most of the control cells displayed only small linear (leak) currents that remained stable throughout the experiments, which lasted up to $1 \mathrm{~h}$. Upon staurosporine application, a slight outwardly rectifying increase in membrane conductance, which changed polarity around $0 \mathrm{mV}(-3 \pm 6 \mathrm{mV} ; n=13$; mean \pm S.D.) could be observed (Figure $3 a$ ). These data could be interpreted as the result of the opening of $\mathrm{Cl}^{-}$and/or nonselective cation channels. However, the observation that current amplitudes and reversal potentials were not significantly altered by replacing extracellular $\mathrm{Na}^{+}$and $\mathrm{K}^{+}$with the impermeant monovalent cation $N$-methyl-D-glucamine $(n=3$, data not shown) strongly suggests that $\mathrm{Cl}^{-}$was the charge carrier. To confirm that the staurosporine-induced current was a $\mathrm{Cl}^{-}$ conductance, cells were challenged with the broad-spectrum $\mathrm{Cl}^{-}$channel blocker 5-nitro-2-(3-phenylpropyl amino) benzoic acid (NPPB, $100 \mu \mathrm{M}, n=5$ ) and the more specific inhibitor of the volume-sensitive $\mathrm{Cl}^{-}$conductance phloretin $(50 \mu \mathrm{M}$; Figure $3 b) .{ }^{29}$ Both NPPB and phloretin rapidly and reversibly reduced the staurosporine-evoked currents to levels that were not significantly different from control currents. The staurosporine effect developed gradually, as first changes in conductance occurred 10-15 min after starting staurosporine application, and ramp currents reached the steady-state magnitude 15-25 min after the onset of the first current rise ( $\sim$-fold increase; Figure $3 c$ and $d$ ). The effect was irreversible, as even upon prolonged ( $>10 \mathrm{~min}$ ) washout with control saline, membrane currents did not diminish. Altogether, these data indicate that in ECV304 cells staurosporine causes a rapid increase in $\mathrm{Cl}^{-}$conductance, which can be
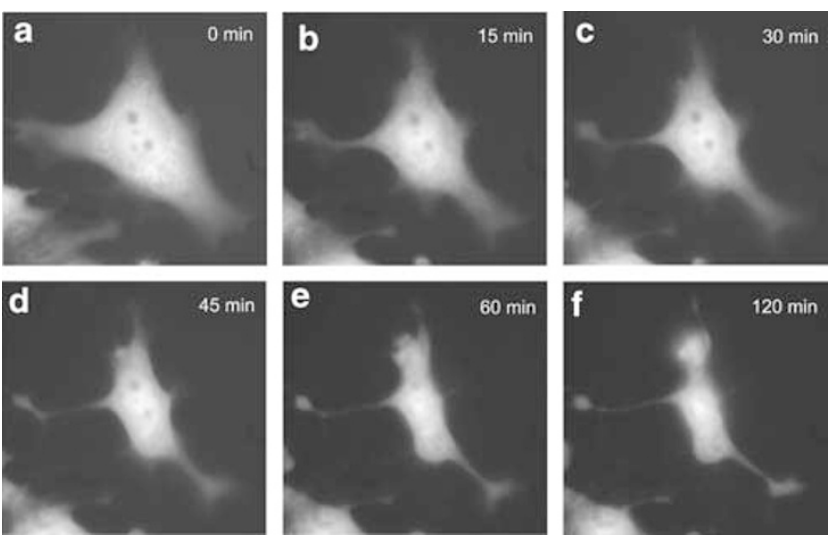

Figure 2 Time course of staurosporine-induced AVD. Cell morphology was evaluated by visualizing live GFP-transfected cells with a high-resolution digital imaging system ( $\times 60$ objective), as specified in Materials and Methods. Typical cell observed before (a) and after application of $1 \mu \mathrm{M}$ staurosporine for 15 (b), 30 (c), 45 (d), 60 (e) and 120 (f) min. This set of images is representative of five other similar a

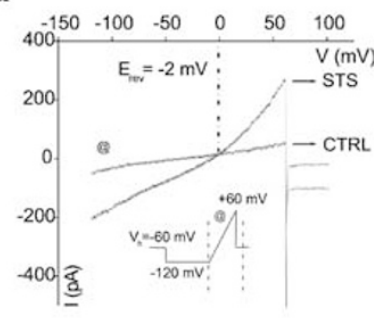

C

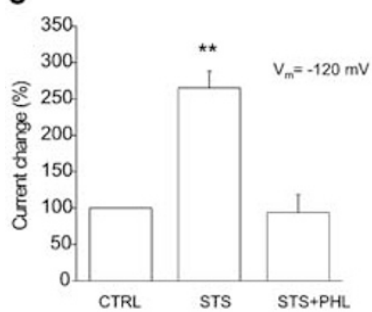

b

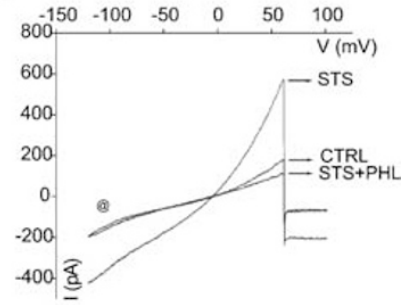

d

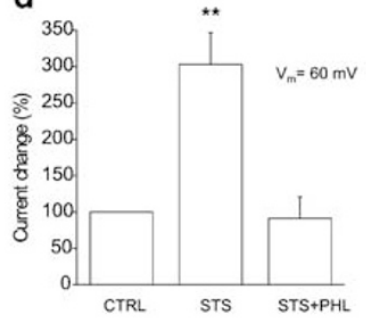

Figure 3 Upregulation of plasma membrane chloride conductance by staurosporine. (a) Representative current traces of voltage clamped ECV304 cell before and after $32 \mathrm{~min}$ exposure to $1 \mu \mathrm{M}$ staurosporine. Tracings relative to the ramp portion (@) of the stimulation paradigm (inset) depict the maximal increase in membrane conductance in the voltage range from -120 to $+60 \mathrm{mV}$ $(1000 \mathrm{~ms} / 180 \mathrm{mV})$ promoted by staurosporine (STS) compared with control condition (CTRL). The voltage intercept of the control and the staurosporineinduced currents denotes that the augmented conductance changed polarity $\left(E_{\text {rev }}\right)$ at $-2 \mathrm{mV}$, which is close to the equilibrium potential for $\mathrm{Cl}^{-}$under our experimental conditions. (b) In another representative cell, the staurosporineactivated ramp current was abrogated by coapplication of the specific $\mathrm{Cl}^{-}$ channel blocker phloretin (PHL; $50 \mu \mathrm{M})$. (c, d) Histograms of the mean $(n=6)$ staurosporine-evoked increase and blockage by phloretin of normalized currents at $-120 \mathrm{mV}(\mathbf{c})$ and $+60 \mathrm{mV}(\mathbf{d}) .{ }^{*} P<0.01$ versus CTRL with Student's $t$-test

counteracted by a specific blocker of swelling-activated $\mathrm{Cl}^{-}$ channels.

To determine whether the activation of $\mathrm{Cl}^{-}$conductance was implicated in the regulation of apoptosis, we examined the effect of some pharmacological $\mathrm{Cl}^{-}$blockers on cell volume and cell viability. Figure 4 illustrates that preincubation with phloretin $(50 \mu \mathrm{M})$ alone had no effect on cell morphology (cfr. Figure $4 \mathrm{a}$ and $\mathrm{c}$ ), whereas it strongly prevented the staurosporine-induced cell shrinkage (cfr. Figure $4 \mathrm{~b}$ and d). Accordingly, the loss of cell viability (Figure $4 \mathrm{e}$ ) as well as the nuclear DNA laddering (Figure 4f) were also abrogated by phloretin cotreatment. A similar effect was observed with $0.1 \mathrm{mM}$ 4,4'-diisothio cyanatostilbene-2,2'-disulfonic acid (DIDS) (data not shown), whereas another broad-spectrum $\mathrm{Cl}^{-}$channel blocker, glibenclamide $(0.5 \mathrm{mM})$, which inhibited AVD and blocked staurosporine-evoked $\mathrm{Cl}^{-}$current, had cytotoxic effect. These results suggest that the upregulation of the plasma membrane $\mathrm{Cl}^{-}$conductance is a crucial event for the triggering and completing of the apoptoptic process.

Since it is possible that staurosporine-evoked increase in $\mathrm{Cl}^{-}$channel activity may favor the efflux of $\mathrm{HCO}_{3}^{-}$, thereby lowering $\mathrm{pH}_{\mathrm{i}}$, the next set of experiments was carried out in order to determine whether staurosporine was also able to promote cytosolic acidification, and to assess the role of $\mathrm{pH}_{\mathrm{i}}$ changes in ECV304 apoptosis. The data indicate that whereas $\mathrm{pH}_{\mathrm{i}}$ was fairly stable during a $10 \mathrm{~h}$ time period 

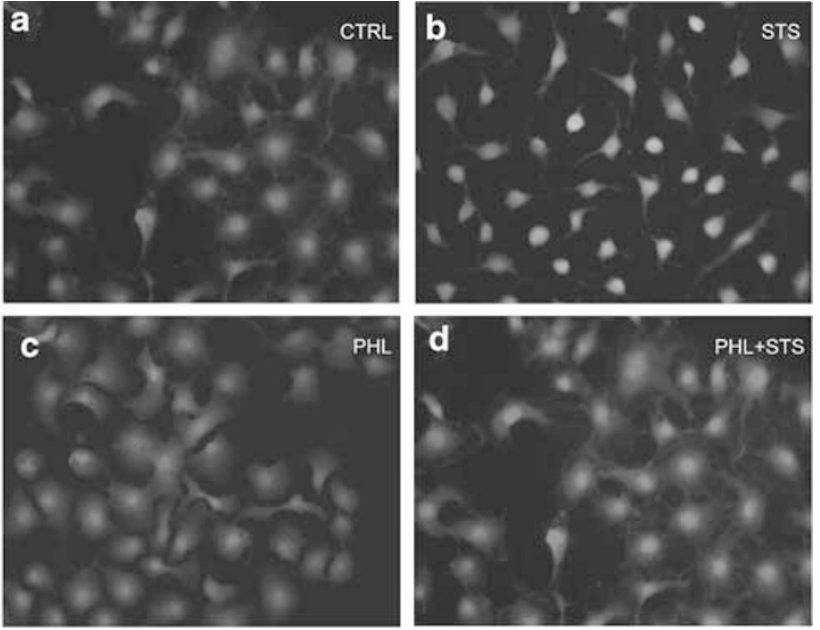

e

f
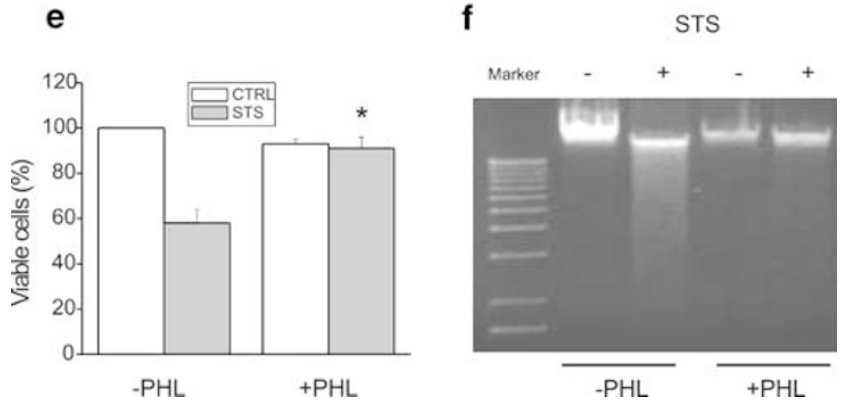

Figure 4 Effect of phloretin on staurosporine-induced AVD, cell viability and nuclear DNA laddering. Cells seeded on coverslips were incubated in M199 medium with $3 \mu \mathrm{M} \mathrm{BCECF/AM}$ for $20 \mathrm{~min}$, washed and then incubated for $1 \mathrm{~h}$ in saline solution alone (a) or in the presence of $50 \mu \mathrm{M}$ phloretin (PHL) (c), or $1 \mu \mathrm{M}$ staurosporine (b), or $1 \mu \mathrm{M}$ staurosporine plus $50 \mu \mathrm{M}$ phloretin (d). Images were captured and analyzed by a digital imaging system ( $\times 40$ objective). Experiments relative to each condition were carried out at least four times. (e) Cells were incubated for $6 \mathrm{~h}$ in growth medium without (-PHL) or with $50 \mu \mathrm{M}$ phloretin (+PHL), in the absence (CTRL) or presence of $1 \mu \mathrm{M}$ staurosporine (STS), and cell viability was determined with MTT assay. Data are means \pm S.D. of $n=4$. ${ }^{*} P<0.05$, with Student's $t$-test, between staurosporine-treated cells without and with phloretin. (f) Nuclear DNA laddering was determined in cells incubated for $16 \mathrm{~h}$ in the absence or presence of $1 \mu \mathrm{M}$ staurosporine without $(-\mathrm{PHL})$ or with (+ PHL) $50 \mu \mathrm{M}$ phloretin. Experiments were performed as described in Figure 1d. A representative determination is shown and data were confirmed in three independent experiments

$(7.31 \pm 0.05, n=6)$, ECV304 cells incubated with staurosporine underwent a significant drop in $\mathrm{pH}_{\mathrm{i}}$ (Figure 5a), which exhibited a biphasic behavior, with a first decrease starting after $3 \mathrm{~h}$ and a peak at $4 \mathrm{~h}(7.02 \pm 0.04, n=5)$, and a second lowering reaching a maximum after $8 \mathrm{~h}(7.05 \pm 0.03, n=5)$. Since previous studies reported that the translocation of the proapoptotic $\mathrm{Bcl}-2$ protein Bax into mitochondria, which leads to cytochrome $c$ release and apoptotic cell death, is regulated by changes in $\mathrm{pH}_{\mathrm{i}},{ }^{17,18}$ we next explored the possibility that such a mechanism, downstream the activation of the $\mathrm{Cl}^{-}$ conductance, might play a role in the stauroporine-induced apoptosis of ECV304 cells. However, the levels of Bax in the mitochondrial fractions isolated from cells treated with staurosporine were not increased during a time period up to $8 \mathrm{~h}$ (Figure $5 \mathrm{~b}$ ), clearly indicating that Bax is not involved in the apoptotic process. To gain further insight into the role of $\mathrm{pH}_{\mathrm{i}}$ a

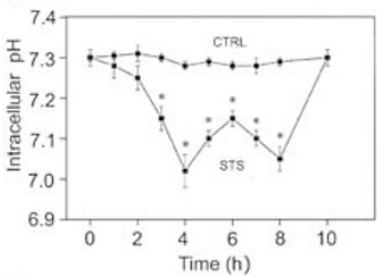

C

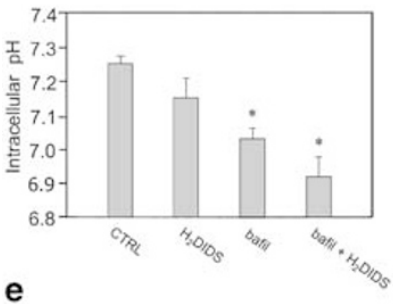

d

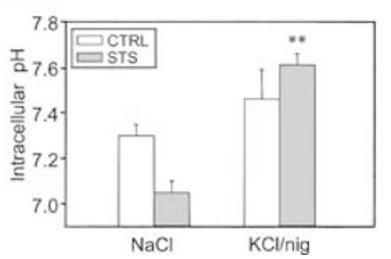

f
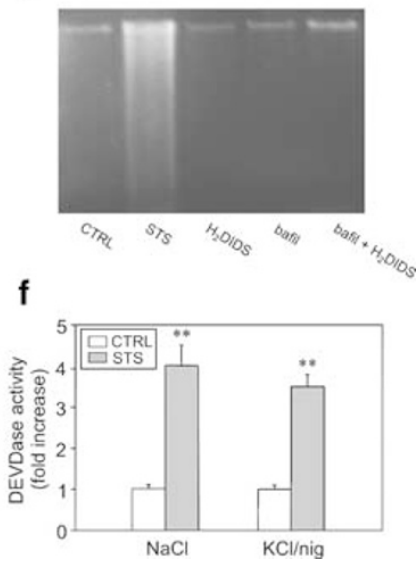

Figure 5 Effects of staurosporine, inhibitors of proton extrusion pathways and changes in $\mathrm{pH}_{\mathrm{i}}$ on DNA laddering, Bax levels and DEVDase activity. (a) ECV304 cells were incubated in serum-free growth medium in the absence (CTRL) or presence of $1 \mu \mathrm{M}$ staurosporine (STS) for the indicated times. Cells were then loaded with BCECF/AM, as described in Materials and Methods. Measurements were carried out in $\mathrm{HCO}_{3}^{-}$-buffered saline solution, under a $5 \% \mathrm{CO}_{2}$ and $95 \% \mathrm{O}_{2}$ atmosphere. Data are means \pm S.D. of three to five determinations. ${ }^{*} P<0.05$ versus CTRL, with Student's $t$-test, at the corresponding time point. (b) The mitochondrial fractions were isolated from cell homogenates as described in Materials and Methods. Mitochondrial proteins $(50 \mu \mathrm{g})$ were separated by SDSPAGE and Bax levels, at different time periods of staurosporine exposure, were determined by Western blotting. The blot shown is representative of three others giving similar results. (c) Cells were incubated for $8 \mathrm{~h}$ in the presence of $50 \mu \mathrm{M}$ $\mathrm{H}_{2}$ DIDS or $10 \mu \mathrm{M}$ bafilomycin (bafil) alone or in combination, and $\mathrm{pH}_{\mathrm{i}}$ was determined as described in Materials and Methods. ${ }^{*} P<0.05$ versus CTRL with Student's $t$-test. (d) ECV304 cells were treated with the various inhibitors for $24 \mathrm{~h}$ and DNA laddering was performed as described in Figure 1d. A representative experiment is shown and data were confirmed in three independent experiments. (e) Cells were incubated for $8 \mathrm{~h}$ in a saline solution containing $115 \mathrm{mM} \mathrm{NaCl}$ ( $\mathrm{NaCl}$ ) or $115 \mathrm{mM} \mathrm{KCl}$ plus $100 \mathrm{nM}$ nigericin (KCl/nig), in the absence (CTRL) or presence of $1 \mu \mathrm{M}$ staurosporine (STS). Changes in $\mathrm{pH}_{\mathrm{i}}$ were determined as described in Figure $5 \mathrm{a}$. Data are means \pm S.D. of three to five determinations. ${ }^{*} P<0.01$, between staurosporine-treated cells in $\mathrm{NaCl}$ and $\mathrm{KCl} / \mathrm{nig}$. (f) DEVDase activity was measured by evaluation of the fluorescence emission of peptide Ac-DEVD-AMC in lysates from cells incubated in the absence (CTRL) or presence of $1 \mu \mathrm{M}$ staurosporine (STS), as described by Ghelli et al. ${ }^{25}$ Data are means \pm S.D. of four to six determinations. ${ }^{* \star} P<0.01$ versus CTRL with Student's $t$-test

acidification in ECV304 apoptosis, measurements were performed in the presence of various ion transporter inhibitors known to affect $\mathrm{pH}_{\mathrm{i}}$. Whereas amiloride, a blocker of the $\mathrm{Na}^{+} /$ $\mathrm{H}^{+}$exchanger, did not modify intracellular $\mathrm{pH}_{\mathrm{i}}$ (data not shown), and an $8 \mathrm{~h}$ incubation with a blocker of the $\mathrm{Cl}^{-} / \mathrm{HCO}_{3}^{-}$ exchanger (4,4'-diisothiocyanatodihydro stilbene-2,2' -disulfonic acid ( $\mathrm{H}_{2}$ DIDS), $50 \mu \mathrm{M}$ ) promoted only a mild acidification, cell treatment with an inhibitor of vacuolar $\mathrm{H}^{+}$ATPase, bafilomycin $\mathrm{A}(10 \mu \mathrm{M})$, elicited a $\mathrm{pH}_{\mathrm{i}}$ decrease comparable with that generated by staurosporine, which was even more 
pronounced when coapplied with $\mathrm{H}_{2}$ DIDS (Figure $5 \mathrm{c}$ ). However, cytosolic acidification did not play a role in the staurosporine-induced ECV304 apoptosis, because none of these treatments caused DNA laddering (Figure 5d). The independence of the staurosporine-induced apoptosis of ECV304 cells from $\mathrm{pH}_{\mathrm{i}}$ acidification was also corroborated by the observation that the incubation of the cells in a high $\mathrm{K}^{+}$ medium containing nigericin $(100 \mathrm{nM})$ clamped $\mathrm{pH}_{\mathrm{i}}$ to a slightly alkaline value also in the presence of staurosporine (Figure 5e), but did not prevent the staurosporine-mediated caspase- 3 activation (Figure $5 f$ ) and DNA laddering (data not shown).

\section{Discussion}

The novel finding described in this study is that in ECV304 cells, the staurosporine-induced apoptotic cell death is characterized by a remarkable AVD, which is dependent on the upregulation of plasma membrane channel-mediated $\mathrm{Cl}^{-}$efflux. We also show that both the activation of $\mathrm{Cl}^{-}$ conductance and cell shrinkage were early events of the apoptotic process, clearly preceding the release of cytochrome $c$ from mitochondria and caspase- 3 activation, which could be detected only after $4 \mathrm{~h}$ incubation with staurosporine. Interestingly, also in U937 cells a significant AVD was detected after $1 \mathrm{~h}$ treatment with staurosporine, whereas caspase-3 activation was not observed up to $2 \mathrm{~h} .{ }^{13}$ Conversely, a remarkable cell shrinkage started after $2-4 \mathrm{~h}$ in Jurkat $\mathrm{T}$ cells treated with anti-Fas antibody or ultraviolet radiation $^{30,31}$ or etoposide ${ }^{32}$ or in dexamethasone-treated rat lymphocytes. $^{2}$ Anti-Fas- ${ }^{14,30,31}$ and etoposide-induced shrinkage of Jurkat cells ${ }^{32}$ was prevented by the general caspase inhibitor z-VAD-fmk, suggesting its dependence on caspase activity. However, cell shrinkage was reported to be z-VAD-fmk insensitive in Jurkat T cells exposed to ultraviolet radiation $^{31}$ or thapsigargin. ${ }^{30}$ Thus, although AVD can be considered as an early event in apoptosis, its occurrence in relation to the activation of the caspase cascade is highly dependent on the death-inducing stimulus, possibly owing to the distinct signalling pathways involved in the process.

By means of electrophysiological technique, we provide evidence that staurosporine generated a rapid increase in plasma membrane $\mathrm{Cl}^{-}$channel activity but did not alter the $\mathrm{K}^{+}$conductance. Whereas the cellular mechanisms whereby channel-mediated $\mathrm{K}^{+}$efflux regulates AVD are beginning to be unveiled (see, for a review, Bortner and Cidlowski ${ }^{5}$ ), the role of transmembrane passive $\mathrm{Cl}^{-}$fluxes remains to be firmly established. $^{33}$ Recently, it was shown that exposure of different cell lines to staurosporine caused apoptotic cell death through mechanism(s) mediated by an early normotonic cell shrinkage, which was sensitive to $\mathrm{Cl}^{-}$and $\mathrm{K}^{+}$ channel blockers. ${ }^{16}$ Moreover, $\mathrm{Cl}^{-}$channel blockers, but not $\mathrm{K}^{+}$channel inhibitors, were reported to prevent staurosporine-mediated apoptosis in brain cells in primary culture. ${ }^{34}$ However, definitive evidence that $\mathrm{Cl}^{-}$channels may play a crucial role in apoptotic cell death is just now beginning to be unfolded. In T-lymphocytes, CD95 receptor stimulation caused apoptotic cell death and a ceramide-dependent opening of an outwardly rectifying $\mathrm{Cl}^{-}$channel. ${ }^{14}$ TNF- $\alpha$ was demonstrated to activate both $\mathrm{K}^{+}$and $\mathrm{Cl}^{-}$channels in liver cells, and individual blockage of $\mathrm{K}^{+}$and $\mathrm{Cl}^{-}$channels delayed, but did not prevent, TNF- $\alpha$-induced apoptosis. ${ }^{13}$ Our data indicate that in ECV304 cells staurosporinemediated apoptotic cell death was strongly attenuated by coapplication of the specific $\mathrm{Cl}^{-}$channel inhibitor phloretin at a concentration that abrogated the staurosporine-induced increase in $\mathrm{Cl}^{-}$conductance. Interestingly, this concentration has been reported to inhibit swelling-activated $\mathrm{Cl}^{-}$channels specifically. ${ }^{29}$ Altogether, these findings depict a causal relationship between upregulation of transmembrane $\mathrm{Cl}^{-}$flux and apoptosis in ECV304 cells. The molecular identity of the $\mathrm{Cl}^{-}$channel protein involved in this effect remains to be identified. Another crucial issue that has to be addressed in future studies is the identification of the downstream apoptotic events, specifically regulated by increased efflux of $\mathrm{Cl}^{-}$and consequent AVD.

Notably, our data indicate that application of staurosporine does not alter the $\mathrm{K}^{+}$conductance in ECV304 cells. However, the involvement of $\mathrm{K}^{+}$channels in AVD cannot be completely ruled out as electrophysiological experiments were conducted in normotonic conditions. Given that elevated extracellular $\mathrm{K}^{+}$ depressed AVD, but that incubation with several $\mathrm{K}^{+}$channel blockers was unable to prevent staurosporine-induced AVD and apoptosis (our unpublished observation), it can be envisaged that multiple pathways may exist for the loss of cellular $\mathrm{K}^{+}$during the cell death process, depending on the cell type and/or apoptotic stimulus. ${ }^{5}$ Thus, since the blockade of $\mathrm{Cl}^{-}$efflux was able to inhibit AVD, we can conclude that the staurosporine-evoked increase in $\mathrm{Cl}^{-}$conductance is both necessary and sufficient for AVD.

The staurosporine-induced increase in $\mathrm{Cl}^{-}$conductance, by also allowing the efflux of $\mathrm{HCO}_{3}^{-}$might contribute, at least in part, to the significant decrease in $\mathrm{pH}_{\mathrm{i}}$ observed upon staurosporine exposure. However, although cytosolic acidification is a very reproducible event, the results presented here clearly suggest that it is a secondary effect, which cannot account for the ability of staurosporine to induce cell death. Indeed, the translocation into the mitochondria of the proapoptotic protein Bax was not favored by cytosolic acidification. Moreover, no significant DNA laddering was detected following cell treatment with the inhibitor of $\mathrm{H}^{+}$ATPase bafilomycin alone or in conjunction with the anion exchanger blocker $\mathrm{H}_{2}$ DIDS. Finally, $\mathrm{pH}_{\mathrm{i}}$ alkalinization with a high $\mathrm{K}^{+}$medium in the presence of nigericin did not depress both the staurosporine-mediated caspase-3 activation and DNA laddering. This latter finding is different from that reported in somatostatin-induced apoptosis of MCF-7 cells by Liu and co-workers, who showed that $\mathrm{pH}_{\mathrm{i}}$ elevation completely inhibited caspase-3/7 activity as well as cytochrome $c$ release into the cytosol. ${ }^{24}$ It must be pointed out, however, that it is also possible that the $\mathrm{pH}_{\mathrm{i}}$ reduction (from 7.4 to 7.0 ) generated by the inhibition of the $\mathrm{H}^{+}$extrusion was just not sufficient for triggering the apoptotic process in ECV304 cells, a conclusion corroborated by the observation that MCF-7 cells underwent apoptosis only when $\mathrm{pH}_{\mathrm{i}}$ ranged between 6.0 to 6.5 , but never at values above $7.0 .^{22}$

In conclusion, this study shows that in ECV304 cells there is a clear interplay between staurosporine-induced apoptosis, AVD and channel-mediated $\mathrm{Cl}^{-}$fluxes. We also provide 
evidence that the upregulation of the plasma membrane $\mathrm{Cl}^{-}$ current is a causal factor in AVD. Since to our knowledge this is the first report demonstrating the exclusive involvement of a $\mathrm{Cl}^{-}$conductance in the regulation of apoptotic cell death, ${ }^{13,16}$ these data support the tenet that $\mathrm{Cl}^{-}$channels may be a novel molecular target for the development of alternative strategies aimed to the control of apoptotic processes. Additional research is necessary to determine whether this is a mechanism that applies only to cell lines or it can mediate the apoptotic cell death in a native context of cells from normal tissues and organs.

\section{Materials and Methods}

\section{Materials}

Staurosporine, MTT, nigericin and protease inhibitors cocktail were from Sigma (St. Louis, MO, USA). Antibodies against cytochrome c, Bax, procaspase-3 and secondary antibodies were purchased from Santa Cruz Biotechnology (Santa Cruz, USA). Caspase-3 substrate (Ac-DEVD-AMC) was from Calbiochem (La Jolla, USA). BCECF/AM was purchased from Molecular Probes (Eugene, USA).

\section{Cell culture and incubation conditions}

ECV304 cells were grown in M199 medium containing 10\% fetal calf serum (FCS), $2 \mathrm{mM}$ L-glutamine, $100 \mathrm{U} / \mathrm{ml}$ penicillin and $100 \mu \mathrm{g} / \mathrm{ml}$ streptomycin. For the experiments, cells $\left(1 \times 10^{6}\right)$ were incubated in M199 medium without FCS in the absence or presence of $1 \mu \mathrm{M}$ staurosporine, unless otherwise indicated. To clamp the $\mathrm{pH}_{\mathrm{i}}$, cells were incubated in a saline solution (high $\mathrm{K}^{+}$medium) containing (in $\mathrm{mM}$ ): $115 \mathrm{KCl}, 2 \mathrm{KH}_{2} \mathrm{PO}_{4}$, $1 \mathrm{MgSO}_{4}, 10$ glucose, $1 \mathrm{CaCl}_{2}, 25 \mathrm{mM} \mathrm{NaHCO}_{3}$ in the presence of $100 \mathrm{nM}$ nigericin.

\section{Cell viability}

The percentage of viable cells was measured with the colorimetric MTT assay, as described previously. ${ }^{35}$

\section{Caspase-3 assay}

Caspase- 3 activity was determined by cleavage of procaspase- 3 by means of Western blot. Cells were incubated with staurosporine, harvested, centrifuged and the pellets resuspended in phosphate salinebuffered solution (PBS) containing 1\% triton X-100, 0.5 mM EDTA, 0.6 mM PMSF and $100 \mu \mathrm{l} / \mathrm{ml}$ of protease inhibitors cocktail, frozen and thawed twice, sonicated for $1 \mathrm{~min}$ and centrifuged for $2 \mathrm{~min}$ at $10000 \times \mathrm{g}$. Protein content was determined by Bradford. ${ }^{36}$ Proteins $(80 \mu \mathrm{g})$ from cell lysates were separated by $12 \%$ SDS-PAGE and transferred onto nitrocellulose membrane (Bio-Rad, Hertfordshire, UK). The membrane was treated with $5 \%$ nonfat milk in TBS-Tween $0.05 \%$ for $1 \mathrm{~h}$ and incubated with the primary antibody for $1 \mathrm{~h}$ at room temperature. The anti-procaspase-3 primary antibodies were diluted 1:1000. Antigen-antibody complexes were detected by using horseradish peroxidase-conjugated secondary antibodies diluted 1:2000 in TBS-Tween $0.05 \%$, supplemented with $5 \%$ nonfat milk and incubated for $20 \mathrm{~min}$ at room temperature. The chemiluminescence signals were revealed using an ECL Western blotting kit (Amersham Bioscience, Buckinghamshire, UK) and measured with the Fluo-2 MAX Multimager system (Bio-Rad, Herthfordshire, UK). Since caspase-3 can cleave the Ac-DEVD-AMC substrate, in some experiments the increase in caspase-3 activity was determined as changes in DEVDase activity, as described previously. ${ }^{25}$

\section{DNA fragmentation}

Chromosomal DNA was extracted from cells as reported ${ }^{37}$ and DNA was loaded onto a $1 \%$ agarose gel, electrophoresed and stained with ethidium bromide.

\section{Subcellular fractionation}

Cells were centrifuged and the pellet was resuspended in $200 \mathrm{mM}$ mannitol, $70 \mathrm{mM}$ sucrose, $1 \mathrm{mM}$ EGTA, $10 \mathrm{mM}$ HEPES (pH 7.6) and homogenised for 30 strokes with a Dounce homogenizer. This and the subsequent steps were carried out at $4^{\circ} \mathrm{C}$. Samples were centrifuged for $10 \mathrm{~min}$ at $500 \times g$ and the resulting supernatant was centrifuged $20 \mathrm{~min}$ at $10000 \times g$. The supernatant (cytosolic fraction) was stored at $-80^{\circ} \mathrm{C}$. The pellet (mitochondrial fraction) was suspended in PBS containing $1 \%$ triton X-100, $0.5 \mathrm{mM}$ EDTA, 0.6 mM PMSF and $100 \mu \mathrm{l} / \mathrm{ml}$ of protease inhibitors cocktail and stored at $-80^{\circ} \mathrm{C}$. Proteins $(50-80 \mu \mathrm{g})$ were separated by $12 \%$ SDS-PAGE or by $15 \%$ tricine-SDS-PAGE ${ }^{38}$ for Bax or cytochrome $c$, respectively, and transferred into nitrocellulose. The anticytochrome $c$ primary antibodies were diluted 1:500, while the anti-Bax antibody $1: 1000$. Antigen-antibody complexes were detected by using horseradish peroxidase-conjugated secondary antibodies diluted 1:2000 in TBS-Tween $0.05 \%$ supplemented with $5 \%$ nonfat milk and incubated for $20 \mathrm{~min}$ at room temperature $\left(20-22^{\circ} \mathrm{C}\right)$. The chemiluminescence signals were measured as above.

\section{Morphological analysis of cells}

Cells were seeded onto $24 \mathrm{~mm}$ coverslips and transfected with $8 \mu \mathrm{g}$ of DNA of GFP, using the $\mathrm{Ca}^{2+}$-phosphate technique and experiments were performed $36 \mathrm{~h}$ after transfection. ${ }^{39}$ The coverslips with the cells were transferred to a temperature-controlled stage of a digital imaging system and incubated for the times indicated. The system was composed of an inverted epifluorescence microscope Nikon Eclipse 300, with a backilluminated CCD camera (Princeton Instruments, USA) and acquisition/ analysis software Metamorph (Universal Imaging Corporation, USA), as described previously. ${ }^{40}$ Images of individual cell were captured before and after staurosporine addition at defined time intervals. Alternatively, in some experiments, cells were loaded with BCECF/AM for $15 \mathrm{~min}$, washed, treated as indicated in the figure legend, and images collected with the imaging system at defined time periods.

\section{Cellular electrophysiology}

For electrophysiological experiments ECV304 cells were seeded at low density in 35-mm-diameter dishes and used within 2 days of replating. Plasma membrane whole-cell currents were recorded at room temperature $\left(20-22^{\circ} \mathrm{C}\right)$ with the perforated-patch configuration of the patch-clamp technique. ${ }^{41}$ This configuration allows the measurements of ionic currents without altering the cytoplasmic pool of enzymes and metabolites that may be essential for channel modulation. To this end, the polyene antibiotic amphotericin B (Sigma, Italy), which forms nonselective ion-permeable pores, was added into the pipette solution. ${ }^{42}$ To avoid difficulties during seal formation, the recording pipette was back-filled with amphotericincontaining intracellular saline $(250 \mu \mathrm{g} / \mathrm{ml})$, whereas the pipette tip contained the standard internal solution (tip resistance 3-4M $\Omega$ ). As amphotericin B solution gradually loses its efficacy, pipette solution 
containing amphotericin B was prepared freshly every $2-3 \mathrm{~h}$. Membrane currents were amplified (EPC-7, List Electronic, Germany), low-pass filtered at $3 \mathrm{kHz}$ and stored in a microcomputer for off-line analysis (pClamp 6.0, Axon Instruments, USA and Origin 5.0, Microcal, USA). During the recordings series resistances $(<20 \mathrm{M} \Omega)$ and capacitive currents were compensated for with the analog circuits of the amplifier; membrane currents were considered for analysis only when series resistance did not change by more than $15 \%$ throughout the experiment. Liquid junction potentials $(<5 \mathrm{mV})$ due to the use of different intra- and extracellular solutions at the beginning of the experiments were not compensated for. The bathing solution was composed of $(\mathrm{mM}): 140 \mathrm{NaCl}$, $4 \mathrm{KCl}, 2 \mathrm{CaCl}_{2}, 2 \mathrm{MgCl}_{2}, 10 \mathrm{TES}, 5$ glucose, pH 7.4 adjusted with $\mathrm{NaOH}$. The standard internal (pipette) saline was: $144 \mathrm{KCl}, 2 \mathrm{MgCl}_{2}, 10 \mathrm{TES}, 5$ EGTA with $\mathrm{pH}$ adjusted to 7.2 with $\mathrm{KOH}$. For experiments of ionic substitution, salts were replaced equimolarly. The various solutions were applied with a gravity-driven microperfusion system. Data are presented as mean \pm S.D. and statistical analysis was performed with Student's $t$ test. A $P<0.05$ was taken as the level of significance.

\section{$\mathrm{pH}_{\mathrm{i}}$ measurements}

Cells were treated with staurosporine for the defined time periods, detached from the flask by trypsinization and $\mathrm{pH}_{\mathrm{i}}$ was determined as reported. ${ }^{25}$ Briefly, cells were incubated in DMEM with $3 \mu \mathrm{M} 2^{\prime}, 7^{\prime}$-bis(2carboxyethyl)-5(6)carboxyfluorescein tetraacetoxymethyl ester (BCECF/ AM) for $30 \mathrm{~min}$ in a $\mathrm{CO}_{2}$ incubator. Cells were then washed twice, incubated in DMEM and kept in the dark until use. Aliquots of $3 \times 10^{5}$ cells were suspended in $\mathrm{HCO}_{3}^{-}$-buffered $\mathrm{NaCl}$ solution containing (in $\mathrm{mM}$ ) 115 $\mathrm{NaCl}, 3 \mathrm{KCl}, 2 \mathrm{KH}_{2} \mathrm{PO}_{4}, 1 \mathrm{MgSO}_{4}, 10$ glucose, $1 \mathrm{CaCl}_{2}, 25 \mathrm{NaHCO}_{3}$ (bubbled with $95 \% \mathrm{O}_{2}-5 \% \mathrm{CO}_{2}$ mixture for several minutes before use, $\mathrm{pH}$ 7.4). Fluorescence measurements (excitation and emission wavelengths of 505 and $530 \mathrm{~nm}$, respectively) were carried out with a Jasko spectrofluorimeter F-770 (Tokyo, Japan) at $37^{\circ} \mathrm{C}$, under continuous stirring, in an atmosphere of $95 \% \quad \mathrm{O}_{2}-5 \% \mathrm{CO}_{2}$ mixture. Calibration of BCECF fluorescence against $\mathrm{pH}_{\mathrm{i}}$ was obtained by incubating an aliquot of cells in a high $\mathrm{K}^{+}$saline solution containing $2 \mu \mathrm{M}$ nigericin. Fluorescence correlated linearly with $\mathrm{pH}_{\mathrm{i}}$ changes over the $\mathrm{pH}$ range between 6.4 and 8.0 .

\section{Acknowledgements}

This work was supported by grants from PRIN 2002 'I mitocondri nella fisiopatologia cellulare: meccanismi patogenetici e sintesi di nuovi farmaci', Progetto Dipartimentale 'Biologia della riproduzione e dello sviluppo: aspetti morfologici e funzionali', University of Bologna to MR and FIRB grant (RBNE01ARR4003) from MIUR (Italy) to SF. We are gratefully to Dr. P Pinton and Professor R Rizzuto, University of Ferrara, for the generous gift of GFP and for making available the Telethon Cell Imaging Facility.

\section{References}

1. Bortner CD, Hughes FM and Cidlowski JA (1997) A primary role for $\mathrm{K}^{+}$and $\mathrm{Na}^{+}$ efflux in the activation of apoptosis. J. Biol. Chem. 272: 32436-32442

2. Hughes FM, Bortner CD, Purdy GD and Cidlowski JA (1997) Intracellular $K^{+}$ suppresses the activation of apoptosis in lymphocytes. J. Biol. Chem. 272: 30567-30576

3. Lang F, Ritter M, Gamber N, Huber S, Fillon S, Tanneur V, Lepple-Wienhues A, Szabo I and Gulbins E (2000) Cell volume in the regulation of cell proliferation and apoptotic cell death. Cell. Physiol. Biochem. 10: 417-428
4. Okada Y, Maeno E, Shimizu T, Cesari S, Wang J and Miroshoma S (2001) Receptor mediated control of regulatory volume decrease (RVD) and apoptotic volume decrease (AVD). J. Physiol. 532: 3-16

5. Bortner CD and Cidlowski JA (2002) Cellular mechanisms for the repression of apoptosis. Annu. Rev. Pharmacol. Toxicol. 42: 259-281

6. Yu SP, Yeh C-H, Sensi SL, Gwag BJ, Canzoniero LM, Farhangrazi ZS, Yiiing HS, Tian M, Dugan LL and Choi DW (1997) Mediation of neuronal apoptosis by enhancement of outward potassium channel. Science 278: 114-117

7. Yu SP, Yeh, Gottron F, Wang X, Grabb MC and Choi DW (1999) Role of outward delayed rectifier $\mathrm{K}^{+}$current in ceramide-induced caspase activation and apoptosis in cultured cortical neurons. J. Neurochem. 73: 933-941

8. Storey SM, Gomez-Angelats M, Bortner CD, Amstrong DL and Cidlowski JA (2003) Stimulation of Kv1.3 potassium channels by death receptors during apoptosis in Jurkat T lymphocytes. J. Biol. Chem. 278: 33319-33326

9. Krick S, Platoshyn O, Sweeney M, Kim H and Yuan JXL (2001) Activation of $\mathrm{K}^{+}$ channels induces apoptosis in vascular smooth muscle cells. Am. J. Physiol. 280: C970-C979

10. Elliott JI and Higgins CF (2003) IKCa1 activity is required for cell shrinkage, phosphatidylserine translocation and death in T lymphocyte apoptosis. EMBO Rep. 4: 189-194

11. Trimarchi JR, Liu L, Smith PJS and Keefe DL (2002) Apoptosis recruits twopore domain potassium channels used for homeostatic volume regulation. Am. J. Physiol. 282: C588-C594

12. Lauritzen I, Zanzouri M, Honoré E, Duprat F, Ehrengruber MU, Ladzunski M and Patel AJ (2003) $\mathrm{K}^{+}$-dependent cerebellar granule neuron apoptosis. Role of TASK leak K+ channels. J. Biol. Chem. 278: 32068-32076

13. Nietsch HH, Roe MW, Fiekers JF, Moore AL and Lidofsky SD (2000) Activation of potassium and chloride channels by tumor necrosis factor- $\alpha$. J. Biol. Chem. 245: 20556-20561

14. Szabò I, Lepple-Wienhues A, Kaba KN, Zoratti M, Gulbins E and Lang F (1998) Tyrosine kinase-dependent activation of a chloride channel in CD95-induced apoptosis in T lymphocytes. Proc. Natl. Acad. Sci. USA 95: 6169-6174

15. Soutkani R, Berdeaux A, Ghaleh B, Giudicelli JF, Guize L, Le Heuzey JY and Henry P (2000) Induction of apoptosis using sphingolipids activates a chloride current in Xenopus laevis oocytes. Am. J. Physiol. 279: C158-C165

16. Maeno E, Ishizaki $Y$, Kanaseki T, Hazama A and Okada Y (2000) Normotonic cell shrinkage because of disordered volume regulation is an early prerequisite to apoptosis. Proc. Natl. Acad. Sci. USA 97: 9487-9492

17. Khaled AR, Kim K, Hofmaister R, Muegge K and Durum SK (1999) Withdrawal of IL-7 induces Bax translocation from cytosol to mitochondria through a rise in intracellular pH. Proc. Natl. Acad. Sci. USA 96: 14476-14481

18. Tafani M, Chon JA, Karpinich NO, Rothman RJ, Russo MA and Farber JL (2002) Regulation of intracellular pH mediates Bax activation in HeLa cells treated with staurosporine or tumor necrosis factor- $\alpha$. J. Biol. Chem. 277: 49569-49576

19. Li J and Eastman A (1995) Apoptosis in an interleukin-2-dependent cytotoxic T lymphocyte cell line is associated with intracellular acidification. Role of the $\mathrm{Na}^{+} /$ $\mathrm{H}^{+}$antiport. J. Biol. Chem. 270: 3203-3211

20. Meisenholder GW, Martin SJ, Green DR, Nordberg J, Babior BM and Gottlieb RA (1996) Events in apoptosis. Acidification is downstream of protease activation and bcl-2 protection. J. Biol. Chem. 271: 16260-16262

21. Gottlieb RA, Giesing HA, Zhu JY, Engler RL and Babior BM (1995) Cell acidification in apoptosis: granulocyte colony-stimulating factor delays programmed cell death in neutrophils by up-regulating the vacuolar $\mathrm{H}^{+}$ATPase. Proc. Natl. Acad. Sci. USA 92: 5965-5968

22. Thangaraju M, Sharma K, Liu D, Shen S-H and Srikant CB (1999) Interdependent regulation of intracellular acidification and SHP-1 in apoptosis. Cancer Res. 59: 1649-1654

23. Matsuyama S, Llopis J, Laveraux QL, Tsien RY and Reed JC (2000) Changes in intramitochondrial and cytosolic $\mathrm{pH}$ : early events that modulate caspase activation during apoptosis. Nat. Cell Biol. 2: 318-325

24. Liu D, Martino G, Thangaraju M, Sharma M, Halwani F, Shen SH, Patel YC and Srikant CB (2000) Caspase-8-mediated intracellular acidification precedes mitochondrial dysfunction in somatostatin-induced apoptosis. J. Biol. Chem. 275: 9244-9250

25. Ghelli A, Porcelli AM, Zanna C and Rugolo M (2002) 7-ketocholesterol and staurosporine induce opposite changes in intracellular $\mathrm{pH}$, associated with distinct types of cell death in ECV304 cells. Arch. Biochem. Biophys. 402: 208-217 
26. Gorman A, Mc Carthy J, Funicane D, Reville W and Cotter T (1996) Morphological assessment of apoptosis. In Techniques in Apoptosis. A User's Guide Cotter TG, Martin SJ (eds) London: Portland Press pp. 2-20

27. Berridge MV, Tan AS, McCoy KD and Wang R (1996) The biochemical and cellular basis of cell proliferation assays that use tetrazolium salts. Biochemica 4: $15-20$

28. Adrian C and Martin SJ (2001) The mitochondrial apoptosome: a killer unleashed by the cytochrome seas. Trends Biochem. Sci. 26: 390-397

29. Fan HT, Morishima S, Kida H and Okada Y (2001) Phloretin differentially inhibits volume-sensitive and cyclic AMP-activated, but not Ca-activated, $\mathrm{Cl}^{-}$ channels. Br. J. Pharmacol. 133: 1096-1106

30. Bortner CD and Cidlowski JA (1999) Caspase independent/dependent regulation of $\mathrm{K}^{+}$, cell shrinkage, and mitochondrial membrane potential during lymphocyte apoptosis. J. Biol. Chem. 274: 21953-21962

31. Vu CCQ, Bortner CD and Cidlowski JA (2001) Differential involvement of initiator caspases in apoptotic volume decrease and potassium efflux during Fas- and UV-induced cell death. J. Biol. Chem. 276: 37602-37611

32. Thompson GJ, Langlais C, Cain K, Conley EC and Cohen GM (2002) Elevated extracellular $\left[\mathrm{K}^{+}\right]$inhibits death-receptor- and chemical-mediated apoptosis prior of caspase activation and cytochrome $c$ release. Biochem. J. 357: 137-145

33. Yu SP and Choi DW (2000) lons, cell volume, and apoptosis. Proc. Natl. Acad. Sci. USA 97: 9360-9362

34. Small DL, Tauskela J and Xia Z (2002) Role of chloride but not potassium channels in apoptosis in primary rat cortical cultures. Neurosci. Lett. 334: 95-98
35. Ghelli AM, Zanna C, Porcelli AM, Schapira AHV, Martinuzzi A, Carelli V and Rugolo M (2003) Leber's Hereditary Optic Neuropathy (LHON) pathogenic mutations induce mitochondrial-dependent apoptotic death in transmitochondrial cells incubated with galactose medium. J. Biol. Chem. 278: $4145-4150$

36. Bradford MM (1976) A rapid and sensitive method for the quantitation of microgram of proteins utilising the principles of protein-dye binding. Anal. Biochem. 72: 248-254

37. Murgia M, Pizzo P, Sandonà D, Zanovello $P$, Rizzuto $R$ and Di Virgilio $F$ (1992) Mitochondrial DNA is not fragmented during apoptosis. J. Biol. Chem. 267: 10939-10941

38. Schägger H. and von Jagow G (1987) Tricine-sodium dodecyl sulfatepolyacrylamide gel electrophoresis for the separation of proteins in the range from 1 to $100 \mathrm{kDa}$. Anal. Biochem. 166: 368-379

39. De Giorgi F, Ahmed Z, Bastianutto C, Brini M, Jouaville LS, Marsault R, Murgia M, Pinton P, Pozzan T and Rizzuto R (1999) Targeting GFP to organelles. Methods Cell Biol. 58: 75-85

40. Porcelli AM, Pinton P, Ainscow EK, Chiesa A, Rugolo M, Rutter GA and Rizzuto R (2001) Targeting of reporter molecules to mitochondria to measure calcium, ATP and pH. Methods Cell Biol. 65: 353-380

41. Horn R and Marty A (1988) Muscarinic activation of ionic currents measured by a new whole-cell recording method. J. Gen. Physiol. 92: 145-159

42. Rae J, Cooper K, Gates P and Watsky M (1991) Low access resistance perforated patch recordings using amphotericin B. J. Neurosci. Methods 37: $15-26$ 